\title{
Epikrateia, Eparchia and a Description of the Carthaginian Presence in Sicily
}

\section{Andrzej Dudziński}

Jagiellonian University, Faculty of History, Institute of History, Gołębia 13, Kraków 31-007, Poland; andrzej.dudzinski@uj.edu.pl

For citation: Dudziński A. Epikrateia, Eparchia and a Description of the Carthaginian Presence in Sicily. Philologia Classica 2021, 16 (1), 4-17. https://doi.org/10.21638/spbu20.2021.101

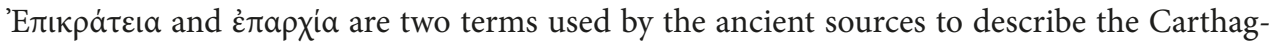
inian presence in Western Sicily. Due to a lack of information about the character and details of this presence, it is crucial to precisely understand the terminology employed by our sources and all its nuances. The article challenges the widely accepted opinion that the nouns


correct or not, a careful analysis of how the ancient authors (Polybius, Diodorus Siculus and Plutarch) used both nouns, as well as other related forms, is conducted. To make up for the

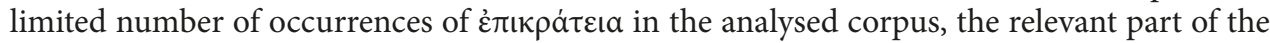
examination also includes the use of this noun in Strabo's Geography. The analysis allows us to highlight a significant change in the meaning of the two terms between the $2^{\text {nd }}$ century (Polybius) and the mid- $1^{\text {st }}$ century BC (Diodorus). This change reflects a development in the Greek political and administrative vocabulary, which was adjusting to a new reality of the Mediterranean world being organised into Roman provinces. The conducted analysis also allows us to better understand the complexity of the Carthaginian position in Western Sicily.

Keywords: Diodorus Siculus, Polybius, Plutarch, eparchy, province, Carthage, Sicily.

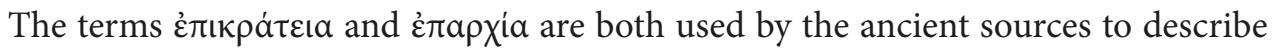
the part of Sicily subject to the Carthaginians. As such, they are important to our understanding of Sicily's status and, by extension, the Carthaginian policy towards such territo-

${ }^{*}$ I would like to thank prof. Sławomir Sprawski who kindly shared his thoughts on the early version of this article, as well as the anonymous reviewers of the Philologia Classica for their helpful suggestions. The research hereby presented would not be possible without the generous funding of the project Relation between historiographical Theory and Praxis in Diodorus Siculus' "Library of History" by the National Science Centre, Poland (2019/32/C/HS3/00114).

(C) St. Petersburg State University, 2021 
ries in Sicily and elsewhere. Modern scholars usually consider the terms synonyms. In this article I put forward the hypothesis that the meaning of both terms evolved over time and that in the majority of our main sources the two terms are indeed very different and by no means interchangeable. To verify this hypothesis, I will first analyse the usage of both terms by the ancient historians who wrote on the history of Sicily (Polybius, Diodorus and Plutarch) and then try to offer an interpretation as to the difference in their meaning.

\section{The status quaestionis}


scribe the Roman province (e. g. Diod. Sic. 40. 4; Plut. Luc. 6. 1; Cic. 30. 1), which makes

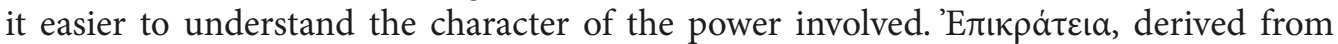

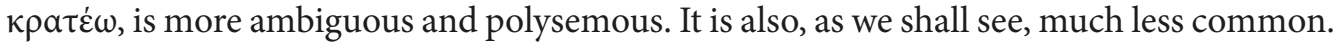
It's earliest recorded use for the Carthaginian part of Sicily can be found in (Ps.-?) Plato's seventh letter (349c).

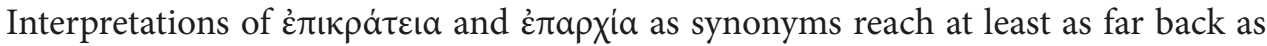
S. Mazzarino's monograph Introduzione alle Guerre Puniche, first published in 1946. The author's definition of this phenomenon influenced a number of later studies. ${ }^{1}$ P. Anello, in her seminal article on the development of the Carthaginian ह̇ंapxia in Sicily, suggested that the choice of terms may reflect the author's preference (with Polybius favouring

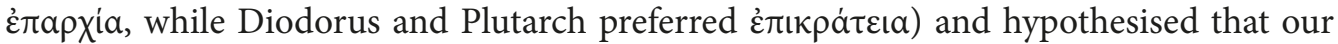
sources, Diodorus most of all, unwittingly projected the reality of the late $4^{\text {th }}$ century (i. e. what Anello considers the proper $\dot{\varepsilon} \pi ı \kappa \rho \dot{\alpha} \tau \varepsilon \alpha / \dot{\varepsilon} \pi \alpha \rho x i \alpha)$ onto the last decade of the $5^{\text {th }}$ century. ${ }^{2}$ The majority of modern scholars adhere to this interpretation, varying slightly in their definitions, but not in the notion that they are dealing with what is essentially a pair of synonyms. ${ }^{3}$

The key reason behind Anello's theory seems to be the necessity to explain the use


when archaeological and literary sources do not offer sufficient evidence to support the existence of any permanent administrative structure remotely resembling the Persian satrapy, the Hellenistic $\dot{\varepsilon} \pi \alpha \rho x i \alpha$ or the Roman province. If one assumes that $\dot{\varepsilon} \pi$ and $\dot{\varepsilon} \pi \alpha \rho x i \alpha$ were used by the ancient authors as synonyms, then one also has to face the resulting difficulty. Anello's hypothesis is an attempt to solve it by suggesting a misunder-

1 “Continuità territoriale 'esclusiva' (...) nell'ambito delle 'province' o eparchie territorialmente definite, si esercita il controllo esclusivistico della potenza dominante, la quale stabilisce i limiti entro cui gli altri possono contrarvi rapporti comerciali" Mazzarino 2003, 65; Anello 1986, 124. For a recent use of a very

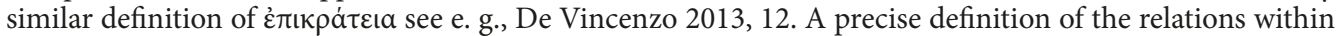
this term is very difficult (probably, as I will argue, by design). For possibly the best attempt to summarise our knowledge, see Ameling 2011, 50-51.


century see also Anello 2008, 97. All dates refer to the times before Christ, unless stated otherwise.

3 E. g. Bondì 1990-1991, 230; Anello 1990-1991, 209; De Vincenzo 2013, 13. Such a view is by no means limited to Italian scholars - it echoes also e. g., in Hans 1983, 119; Miles 2010, 131; Melliti 2016, 118 or Hoyos 2010, 49, although the last two emphasize the complexity of the issue and the limits of our knowledge. Contra see Whittaker 1978, 62-63. New French translations offer, in most cases, a description ("la region soumise aux Carthaginois" in Bonnet and Bennet 1997, 14, 59, "le territoire contrôlé par les Carthaginois" in Goukowsky 2006, 68), but at times use a more direct "les possessions carthaginoises" (e. g., in Diod. Sic. 14, 54, 2: Bonnet and Bennet 1997, 75). 
standing on the part of our sources. For the late $4^{\text {th }}$ century, there is much more evidence for Carthaginian control over Western Sicily, e. g., Carthaginian garrisons appear in the literary and archaeological sources and the local coin emissions disappear, while the legends on Siculo-Punic coinage suggest the appearance of new financial officials. Therefore, Anello suggested that our sources projected the reality of Agathocles' times back onto the last decade of the $5^{\text {th }}$ century - a point at which the Carthaginians re-entered the political landscape of the island. From there, according to the Italian scholar, the Carthaginian presence evolved throughout the next century (with the treaty of 375 marking an important turn), before it finally reached its proper form, deserving the name ह̇ंa $\rho x^{i} \alpha^{4}{ }^{4}$


laid with Diodorus, who drew it from his sources discussing later events. Given that Plutarch used this term as well, it is plausible that it had actually appeared already in Timaeus ${ }^{5}-$ likely a common source for the Sicilian events in Diodorus and Plutarch. Anello's hypoth-

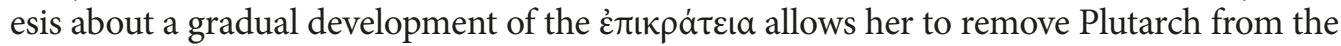
equation. Plutarch used the term at the earliest in reference to Dion's return to Sicily in 356, roughly 50 years after the events for which Diodorus first used it and closer to the reality of

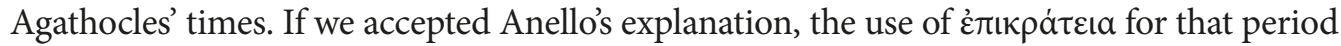
would be much more justified - even if still not entirely appropriate. Nevertheless, this interpretation makes it possible to blame mainly Diodorus for creating confusion due to repeated use of supposedly inappropriate terminology. Such an explanation may have been plausible due to the well-established belief that the Library of History was a work of mere compilation and that its author "lacked the methodical skills of historiography to produce a keen analysis of his time and probably also the intellectual capacity". However, this view of Diodorus and his methods has been questioned for some time. ${ }^{7}$

Anello's explanation is plausible, but it is necessary to keep in mind that it was put forward in order to solve a particular problem - namely that the reality of the late $5^{\text {th }}$ century does not meet the criteria for $\dot{\varepsilon} \pi \iota \kappa \rho \dot{\alpha} \tau \varepsilon ı \alpha / \dot{\varepsilon} \pi \alpha \rho x i \alpha$ proposed by Mazzarino and Anello. This definition rests on the assumption that there is no substantial difference between

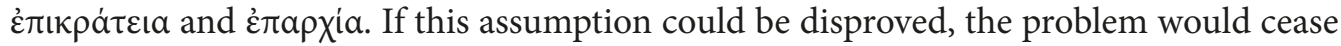
to exist, and we would be left with the task of drawing out the difference between the two terms. Therefore, analysing the relations between them is crucial for our understanding of the history of the Carthaginian presence in Western Sicily.

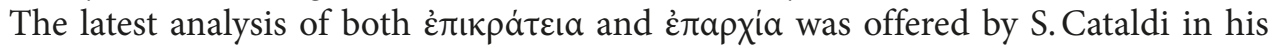
article "Alcune considerazioni su eparchia ed epicrazia cartaginese nella Sicilia Occidentale", published in 2003. In his work, Cataldi analysed the use of these words in the context of the Carthaginian presence in Sicily. ${ }^{8}$ However, his analysis, while comprehensive and

4 Anello 1986, 172-177.

5 Anello 1986, 137-151, following Meister 1967, 71-165 in most cases. For an analysis of the use of Timaean material in the Library of History see Dudziński 2016.

${ }^{6}$ Rathmann 2016, 352-353. This view of Diodorus was offered by Volquardsen 1868 and later firmly established by the authors and editors of RE, most notably Schwartz 1905 and Laqueur 1936, followed by many others e. g., Meister 1967, Pearson 1987.

7 See Palm 1955 on the coherence of the language of the Library of History. A major turn in the studies on Diodorus came with the publication by Sacks 1990.


position in Western Sicily see Anello 1986 and the proceedings of the symposium on this topic printed (with transcripts of discussions following each presentation) in issue XXXVI-XXXVII of "Kokalos" (especially 
thorough, still suffers from the same assumption that both terms describe the same basic

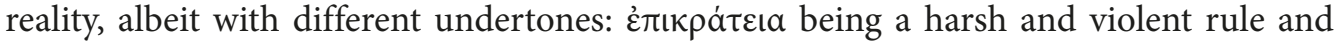
$\dot{\varepsilon} \pi \alpha \rho x i a$ representing a more lenient and legal control over a territory. ${ }^{9}$

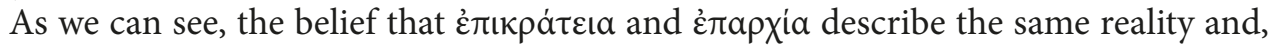
therefore, can be treated as synonymous, is the cornerstone of most historical interpretations concerning the nature of the Carthaginian presence in Sicily. This makes it even more surprising that so far it has not been challenged. In order to verify this assumption, we shall analyse the use of both terms by three major authors and main sources of information concerning the history of Sicily: Polybius, Diodorus Siculus and Plutarch.



Of the three main sources for the history of Sicily, chronologically the earliest one is Histories by Polybius, whose work covered the period from the beginning of the First to the end of the Third Punic War (264-146) providing scholars with invaluable information about the background of these conflicts, in particular about the Romano-Punic treaties.

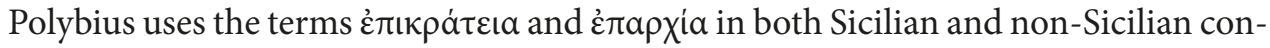
texts. The noun $\dot{\varepsilon} \pi \alpha \rho x i a$ appears in Polybius' work seven times (Polyb. 1. 15. 10; 1. 17. 5; 1. 38. $7 ; 2.19 .2 ; 3.27 .4 ; 3.29 .10 ; 7.4 .2)$ and in all these cases it indicates a territory under the control of a political entity, be it Carthage, Rome or Syracuse. A particularly noteworthy example is Polyb. 2. 19. 2, where Polybius uses $\dot{\varepsilon} \pi \alpha \rho x i a$ to refer to the Roman territory in Italy, which was never a province sensu stricto.

The verb żंá $\rho \chi \omega$ is used extensively in Polybius' translation of the Romano-Punic treaties. Within three chapters (3.22-24), we find four out of the six occurrences of this verb, evidently carrying the meaning "to govern" or "to control" (cf. 21.34. 10; 21. 46. 9).

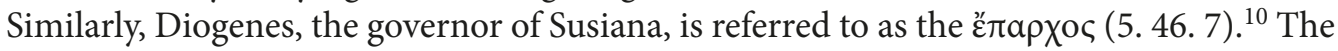

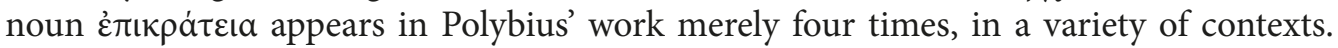

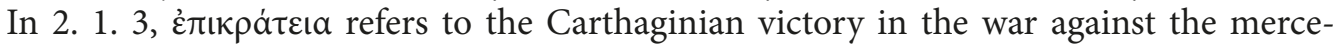
naries in Africa after the First Punic War. Next, Polybius uses this term to describe the danger posed by the Bruttians and the Lucanians to the Greek colonies of Magna Grae-

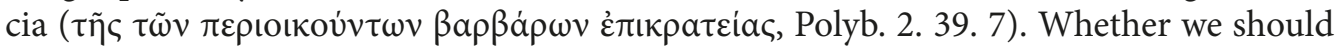

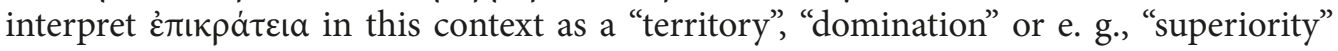
remains open to debate. In 12.25. 3, Polybius refers to the famous bull of Phalaris, saying

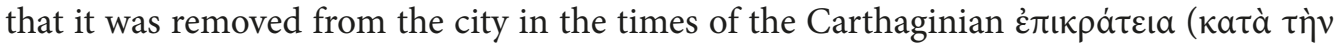


either a "victory", "conquest" or even "superiority". Finally, Polybius uses the term describing Antiochus IV Epiphanus' claim to Coele Syria, citing among the arguments presented

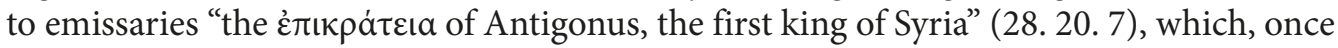

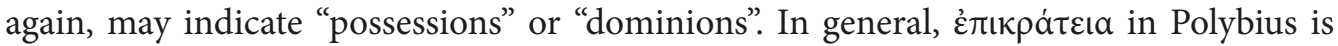
used to denote superiority over someone or something, not necessarily a territory.

Tusa 1990-1991; see also Bondì 1990-1991; Anello 1990-1991). Cataldi’s arguments are considered definitive by De Vincenzo 2013, 13.

9 Cataldi 2003, 218. Cataldi attempted to further support this claim by also pointing out the change in the language of the Athenian honorary decrees of proxenia, where крátoc replaced á $\rho \chi \eta \dot{~ d u r i n g ~ t h e ~ P e-~}$ loponnesian War - a fact he interprets as a reflection of the Athenians' stricter control over their "subjects" during the war (Cataldi 2003, 234-237).

${ }_{10}$ Mauersberger 1961, 866-867 (s.v. ċđapXia). 


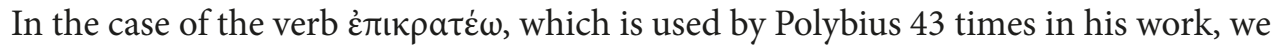
find a very similar range of meanings, although the most common one is "to prevail" or "get the upper hand", used in a variety of contexts ranging from describing a military (e. g., 3. $84.13 ; 6.52 .8)$ or political (4.17.5) victory to even how Danube "overpowers" the sea waves at its mouth (4.41.1-9). There are also examples of this verb used in the context of "conquering" something (2.18.1) or "ruling" (6.50.3). When it comes to control over a territory or an area, $\dot{\varepsilon} \pi \iota \rho \rho \tau \dot{\varepsilon} \omega$ is used mainly in the military context: we find, for example, Rome "controlling" the rest of Sicily during the war against Carthage (1.41.6), or Persians controlling Asia (10.28. 3). It is worth noting that quite often this verb is used to describe control over sea (e. g., 1. 11. 10; 1. 20. 5; 1. 39. 10), which may suggest that indicates military control, or the ability to exert one's power, not any sort of legal authority. ${ }^{11}$

Thus, in Polybius' work the terms in question have different meanings. Most impor-

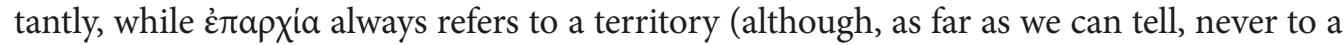



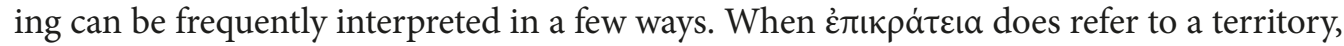
it does not offer any indication as to the administrative character of such a territory - its main focus is on the power that ultimately wields control over it. The fact that the term ¿̇ $\pi$ « $\rho \dot{\tau} \tau \varepsilon \iota \alpha$ is used also to describe Antiochus' claim to Coele Syria seems to contradict Cataldi's interpretation that $\dot{\varepsilon} \pi ı \rho \alpha \dot{\tau} \varepsilon\llcorner a$ is used to depict a harsher and more oppressive rule.

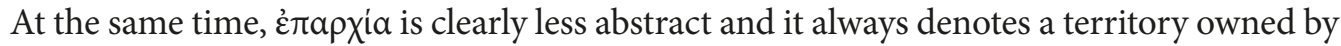
some state. The former term in itself does not carry any information about the status of the territory it describes. It certainly cannot be by default interpreted as a province - a territory forming an administrative unit under the authority of a single official - as it is also used to describe Roman territories in Italia and the Syracusan holdings in Sicily. ${ }^{12}$

This situation changes once we move forward to Diodorus and Plutarch. To better

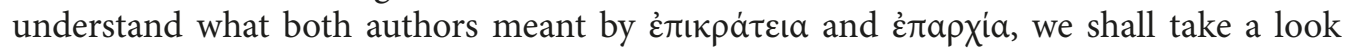
at the use of the two terms throughout their works. While more than half of Diodorus' Library of History did not survive to our times in its entirety, the existing parts and fragments of their works ${ }^{13}$ provide us with ample and diverse material for analysis. In the case of Plutarch, we will focus on the Lives, as the work constitutes a coherent and sufficiently large data set, while representing a biography - a genre akin to historical narrative. ${ }^{14}$

\section{3.'E $\pi \alpha \rho \chi i \alpha$ in Diodorus and Plutarch}

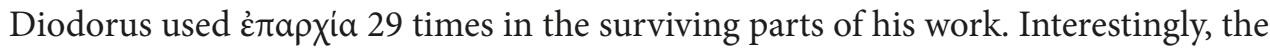
vast majority of these occurrences (24) comes from the second half of his oeuvre (books 21-40 dealing with the period of ca. 301-60 BC) which survived only in fragments. As such, they cover, among other events, the whole existence of the Roman provinces up to



12 It should be noted that the definition of the Latin noun provincia also evolved over time. However, from the very beginning, provincia was associated with an official, indicating where he was supposed to exercise his authority (for an in-depth discussion and examples see Richardson 1992, 564-571).

13 In the Loeb Classical Library series, they are published in 12 vols. The new edition currently being published in the Collection Budé includes all fragments (revised and reorganised) in four volumes.

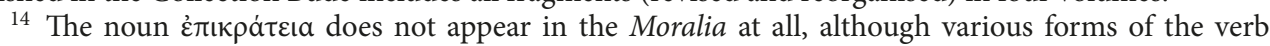




Diodorus' own times. ${ }^{15}$ Unsurprisingly, this is also the meaning in which the term appears most often throughout this part (e. g., 33. 2. 1; 37. 5. 1), also referring to the province of Sicily (e. g., 34/35. 2. 3; 36. 3. 5; 37. 8. 1). However, the same noun is used throughout Diodorus' work to describe administrative units, resembling the Roman province and governed by a single official, in other states (see e. g., Sittacene in 17. 65. 2; Commagene in 31. 19a. 1 or the division of Italy into two consular provinces by the rebels during the Social War in 37. 2. 6). There are also many examples of the term being used in the plural (e. g., 17. 105. 8; 37. 3. 5; 40. 4. 1). Most importantly, however, it is used once - and only once - in the context of the Carthaginian presence in Sicily (22.10.6). ${ }^{16}$



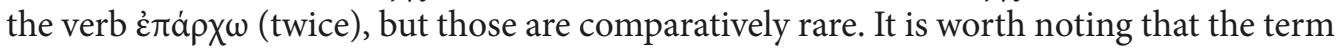

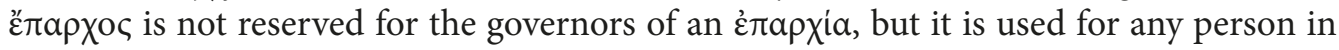
charge, such as a military commander (e. g., 14. 7. 7; 14. 113. 5).

Plutarch, on his part, used ह̇ंapxia 79 times throughout his Lives. Once again, it is mostly used to describe Roman provinces and, therefore, appears predominantly in the biographies of great Romans. In the Greek Lives we find merely three occurrences of this term, one in Pelopidas (30.1) and two in Demetrius (7. 2; 30. 1). Coincidentally, all three are used in the plural. The meaning of the term, therefore, stays the same as in Diodorus: an administrative unit, resembling the Roman province, and governed by a single official. Interestingly, in Plutarch's works we can see the Ė $\operatorname{ta\rho xi} \alpha$ as a predetermined territorial unit

15 In this case in particular the high proportion of occurrences coming from the fragments, surviving only in Byzantine collections of excerpts, brings up the question of their transmission. Naturally, the possibility of the excerptors' intervention in the text cannot be definitively excluded, but from what we can tell about the working methods and criteria behind the major collections of excerpts (such as the Excerpta Constantiniana), their authors emphasised accuracy and while capable of rephrasing their material, they strived to maintain its structure and vocabulary (Manafis 2020, 31-42). In the case of the Excerpta Constantiniana, we can actually see the decision was made to follow the principles of appropriating the excerpts as intact as possible, instead of summarising them (Németh 2018, 56 and Manafis 2020, 39-40). Németh $(2018,86)$ concludes his discussion of the practice of excerpting by stating that "modifications in the Excerpta tended to be minimal and each excerpt carefully followed the original text" and, therefore, "[t]his principle enables scholars to use the Excerpta for the reconstruction of the originals as fragments". In the case of Photius, we can actually see his method of excerpting in direct comparison to Diodorus in the description of the Red Sea (Phot. Bibl. 250. 447B-460A cf. Diod. Sic. 3. 12-48), which was based on the work of Agatharchides of Cnidus in both authors. Palm 1955, 16-26 demonstrated that Photius stayed more faithful to the original text than Diodorus. Therefore, while the excerptor's intervention remains a possibility, it is rather unlikely to have changed the vocabulary used by the author of the source.

16 Walton 1957, 69 in his translation interpreted غ̇лapxia in this passage as the domain of Pyrrhus rather than the Carthaginians. This position is accepted also by Cataldi 2003, 233-234 and Goukowsky 2006, 70 (Diod. Sic. 22. 22. 6), 215 n. 146. The latter notes the problem with the use of this term by Pyrrhus' Sicilian allies and suggests that Diodorus may have "rejuvenated" the speech. However, the context in which

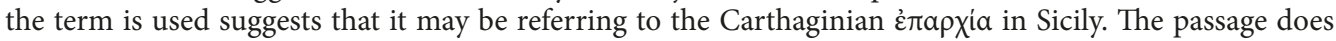
not discuss the king's territorial gains per se, nor Sicily's future status. It refers to his Sicilian allies' goal of forcing the Carthaginians completely out of Sicily. Therefore, the focus of the sentence is firmly on Carthage.

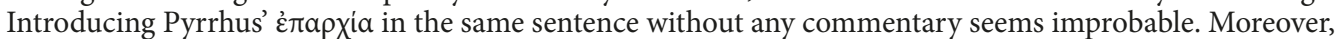
it is very unlikely that Pyrrhus' Sicilian allies would be so willing to give up their independence and become a part of his kingdom, especially if we bear in mind that shortly after, when he executed Thoenon and forced Sosistratus into exile, a number of Sicilian cities turned against him, some of them even joining the Carthaginians (Plut. Pyrrh. 23. 4-5). Furthermore, there is no record of Pyrrhus planning to turn Sicily into an eparchy of his own. The only information on his plans we have comes from Justinus, who claims that Pyrrhus wanted to turn Sicily into a kingdom for his son, Helenus (Just. Epit. 23. 3. 3). Therefore, I would consider the غ̇ंapxia in Diod. Sic. 22. 10. 6 as referring to Carthage rather than Pyrrhus. 
even more clearly - see e. g., Aem. 10.3 for the assignment of provinces by lot, or Cat. Ma. 10. 1 for the province having a proper name. Same as before, we can see $\dot{\varepsilon} \pi \alpha \rho x i \alpha$ used in the plural on numerous occasions (e. g., Luc. 20. 5; Mar. 45. 1). Unlike Diodorus, Plutarch never used this term in the context of the Carthaginian part of Sicily (although it is used for the Roman province in Sicily: Pomp. 61. 1).

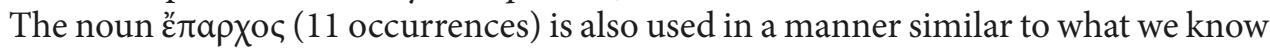
from Diodorus. It is used to describe various people in power, from military commanders

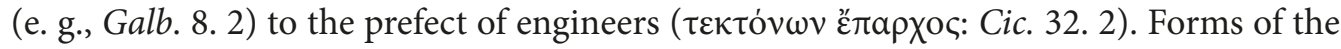
verb غ̇ंá $\rho \chi \omega$ appear very rarely (four occurrences overall).

As we can see, the meaning and the pattern of use of the noun ह̇rapxia remain unchanged between Diodorus and Plutarch, but they differ in one significant way from what we observed in the case of Polybius. Compared to the historian from Megalopolis, who used this term to describe different kinds of territories, both Diodorus and Plutarch employ it in an extremely consistent and precise manner, always referring to an administrative unit governed by a single official - although not necessarily a Roman province (see 17. 65. 2 for a Persian satrapy, 31. 19a. 1 for the Seleucid eparchy of Commagene and 37.2. 6 for two consular provinces of the Socii during the Social War). There is no trace of any ambiguity evident in Polybius' work, such as using żं $\alpha \rho x$ ía to describe Roman territories in Italy or Syracusan in Sicily. It seems that between the times of Polybius and Diodorus the term changed its meaning, becoming much more precise. This process was necessitated by the growing number of Roman provinces, as well as their increasing importance in both the internal and foreign affairs of the Republic. In the $1^{\text {st }}$ century $\mathrm{BC}$, provincial governorship became one of the primary means of advancing one's political career - by providing either an opportunity to wage war or to gather financial resources needed in future campaigns.

It is of particular interest that, while Ėrapxia is widely used by both Diodorus and Plutarch, out of 108 occurrences only one (Diod. Sic. 22. 10.6) appears in the context of the Carthaginian presence in Sicily. Let us now move on to the second term - $\dot{\varepsilon} \pi \iota \kappa \rho \dot{\tau} \tau \varepsilon ı$.



Diodorus used the noun 14 times throughout the surviving parts of his work. The translations "realm", "dominion" and in one case "domination" are suggested in J.I.McDougall's A Lexicon to Diodorus Siculus. ${ }^{17}$ The vast majority of occurrences (13) pertain to the

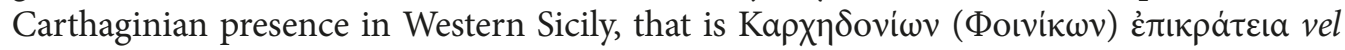
sim. (Diod. Sic. 13. 81. 3; 13. 109. 4; 14. 8. 5; 14. 41. 1; 14. 41. 3; 14. 47. 5; 14. 54. 2; 15. 73. 1; 16. 69. 5; 16. 73. 1; 16. 78. 1; 16. 82. 3; 22. 10. 2). An interesting case is Diod. Sic. 16. 82. 3, where Diodorus relates the terms of the peace treaty between the Carthaginians and Timoleon of Corinth, signed after the crushing defeat of the Carthaginian forces in the battle of Crimissus River. According to Diodorus, the Lycus River was supposed to be the border

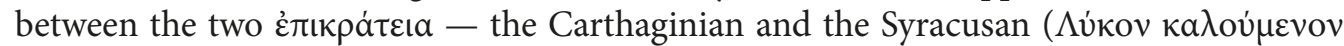

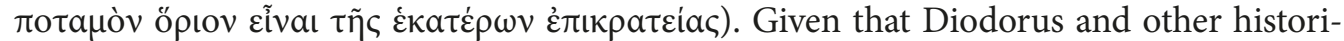


the Syracusan position under his leadership suggests that the term did not carry inher-

17 McDougall 1983, ع 172. 
ently negative connotations. To address this issue, Cataldi points to the absence of the word $\dot{\varepsilon} \pi$ « $\rho \dot{\alpha} \tau \varepsilon ı \alpha$ from Plutarch's version of this treaty, as well as from other known agreements between the Carthaginians and the Greeks. In the centre of his argumentation lies the claim that the official text of the treaty could not possibly have used a "more propagandistic than

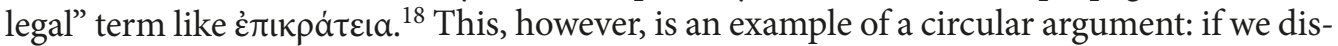
regard evidence against the interpretation of $\dot{\varepsilon} \pi$ ı $\rho \dot{\tau} \tau \varepsilon ı \alpha$ as a negative, propagandistic term, we will inevitably conclude that it was indeed negative and propagandistic. Moreover, the

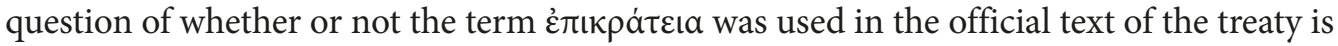
beside the point. The important thing is that Diodorus (certainly well-aware of Timoleon's fame as the liberator of the Sicilian Greeks) apparently considered this term appropriate to describe the part of Sicily subject to Syracuse under the leadership of the Corinthian general. Therefore, it seems that we should not easily disregard this testimony - quite the

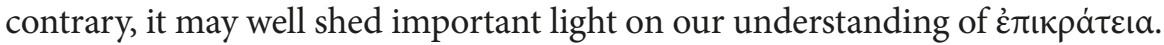

Another example which deserves closer attention is Diod. Sic. 14. 47. 5, where Diodorus remarks that the Acragantines joined the campaign of Dionysius I "hating as they

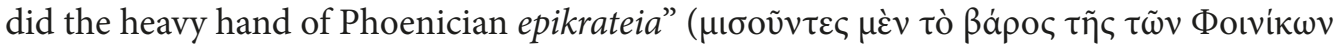
$\varepsilon \dot{\pi}(к \rho \alpha \tau \varepsilon i a \varsigma)$. While the territorial meaning "realm" or "dominion" is still very much possible, a more abstract translation (resembling Polybius' "superiority") seems to be preferable, especially since the given dominating factor is not Carthage, but the Phoenicians. ${ }^{19}$

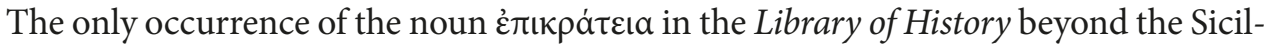
ian context is in the last book, where Diodorus discusses the history and customs of the Jews, citing Hecataeus of Abdera. ${ }^{20}$ Diodorus informs his readers that many Jewish tradi-

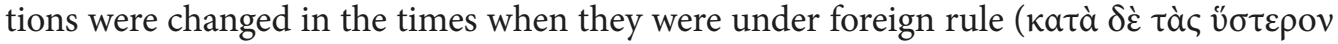

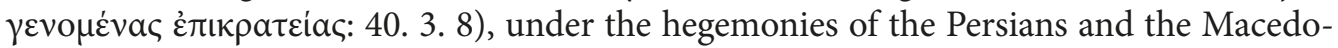

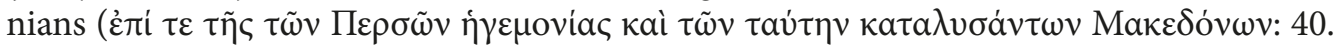
3. 8) ${ }^{21}$ In this context the term clearly means control over the Jews as a people, hence the abstract meaning of "superiority" or "rule" is more appropriate. It is worth noting that Dio-


Especially in reference to the latter, the term can hardly be suspected to carry a clearly negative meaning, particularly as it corresponds to the more common and neutral i $\gamma \varepsilon \mu o v i \alpha$.

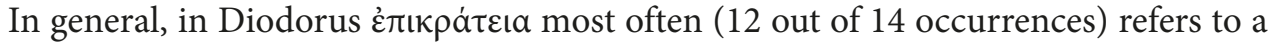
territory under Carthaginian control (with 16. 82. 3 referring to both Carthage and Syracuse); in one further case (14. 47. 5), such a translation is also possible. Only once does the term clearly have a more abstract character (40.3. 8), describing the Jews under the


sage - "hegemony"). The consistent use of the term to describe a territory clearly sets Diodorus apart from Polybius, who evidently used it with a more abstract meaning.

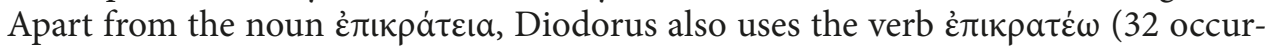
rences throughout his work). The verb maintains a variety of meanings similar to what we have already seen in Polybius' work. The dominant meaning is still "to prevail" or "to win"

18 Cataldi 2003, 225-226.

19 Accordingly, both Oldfather 1954, 145 and Bonnet and Bennett 1997, 68 offer "domination".

20 Photius (cod. 244, pp. 542-543) actually gives the name of Hecataeus of Miletus (Mı $\lambda \dot{\sigma} \sigma ı$ ). Both



${ }^{21}$ It has to be emphasised that in this case we are dealing with a fragment of Diodorus' text preserved in Photius' Library of History. See n. 15 above. 
(e. g., 4. 49. 6; 13. 112. 5; 18. 15. 3), but the term may also be used as "to outnumber" (4. 19. 2; 17. 18. 4). In Diod. Sic. 5. 38. 2, Diodorus uses this verb to talk about the development of silver mining in Iberia under Carthaginian control. In a few other cases, it is also possible to understand $\dot{\varepsilon} \pi \kappa \rho \alpha \tau \dot{\varepsilon} \omega$ as "to control", or something similar, but in general such an interpretation is not necessary. For example, in 34/35.30b. 1 Diodorus points out that it was the weakness of its rivals, rather than its own strength, that contributed to " $\tau \eta \dot{v} v$ P $\mathrm{P} \mu \eta v$

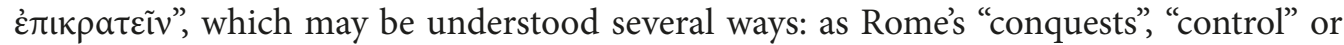
"victory". Similar is the case of Diod. Sic. 37. 27. 1, where Diodorus may be referring to the time when Mithridates was "controlling" Asia, when he was "conquering" it, or when he was "prevailing" there.

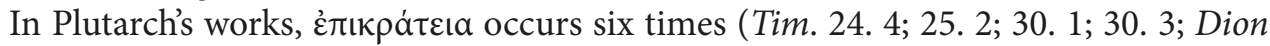
25. 5; Pyrrh. 22. 4). In every case it refers to the part of Sicily under Carthaginian control,


the same pattern, with the meaning "to prevail" still being the most frequent. Like Polybius before him, Plutarch more often than Diodorus used this verb to describe military control, e. g., of a sea (Plut. Sull. 11. 2; Luc. 2. 2) or a river (Plut. Sert. 13. 4). In no case in

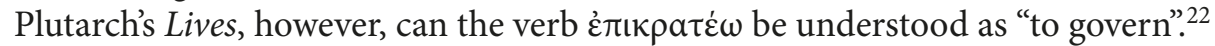

Once again, the patterns of use of the noun $\dot{\varepsilon} \pi$ - $\rho \alpha \dot{\tau} \tau \iota \alpha$ remain virtually the same in Diodorus and Plutarch, but they differ from what we have seen in the case of Polybius.

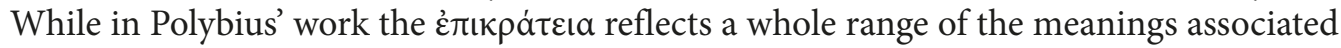
with the verb $\dot{\varepsilon} \pi \kappa \rho \alpha \tau \dot{\varepsilon} \omega$, in the works of Diodorus and Plutarch its meaning is restricted only to the territory subject to a single power (while the possible meanings of the verb remain unchanged). At least in the case of Diodorus, the use of this term to describe the Greek part of Sicily or Macedonian rule over Judea seems to testify against it having a particularly negative character.

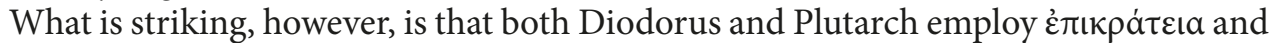
$\dot{\varepsilon} \pi \alpha \rho \chi i \alpha$ in a very consistent manner when it comes to Western Sicily. Both authors use $\dot{\varepsilon} \pi$ « $\rho \alpha \dot{\tau} \varepsilon \iota \alpha$ almost exclusively in the context of the Carthaginian presence in Sicily (19 out of 20 occurrences), while غ̇ंapxía - used 108 times by both authors in total - is only once applied in the same context.

Perhaps the most important observation is that both authors use the noun $\dot{\varepsilon} \pi$ ik almost exclusively in the singular, with the sole exception of Diod. Sic. 40. 3. 8, which discusses the results of the Jews mixing with foreigners under the Persian and Macedonian hegemonies. However, drawing conclusions based on such a limited number of cases would be premature. Therefore, it seems useful to take a look at the use of this term by Diodorus' near contemporary, Strabo (c. 64/63 BC-24 AD).


term appears in many different contexts, such as the spread of Greek dialects (8. 1. 2) or the structure of the "mixed" peoples (14.5.25). However, the vast majority of occurrences


as "conquest" and half of them are related to a particular moment in time (e. g., 5. 1. 1; 16. 1. 19). In five cases, the meaning is more ambiguous and can be translated as "domination"

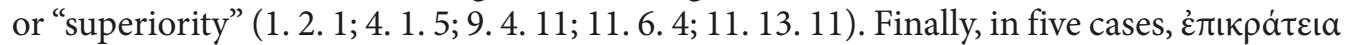

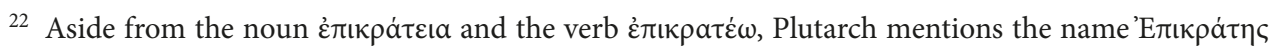
twice. 
clearly refers to a territory of a certain state or city (Rome: 2. 3. 4; Narbonne: 4. 1. 14; Cyrenaea: 17. 1. 5; ancient kings of Egypt: 17. 1. 46; the Libyans and the Aethiopians: 17. 2. 3).

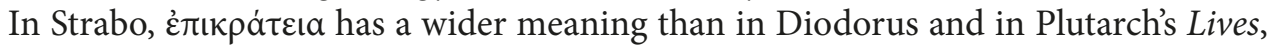
resembling more of Polybius' use of the term. It is, however, important that when it comes to the use of $\dot{\varepsilon} \pi \iota \kappa \rho \alpha \dot{\tau} \tau \varepsilon \_$in the context of territory, Strabo follows closely the same pattern as Diodorus and Plutarch. Indeed, not even once does the noun appear in plural form in

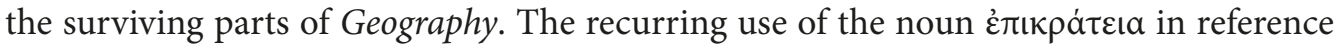
to the Roman domination, domain and conquests seems to confirm that the term did not carry any negative connotation for Strabo.

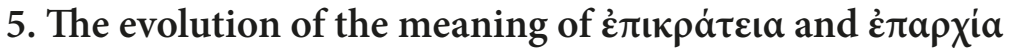

The above analysis allows to make several observations that provide us with information necessary to understand the development of both terms as well as the relationship be-

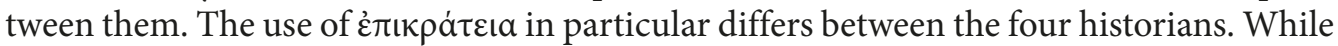
Polybius uses this term in its abstract meaning ("supremacy" vel simile), Diodorus and Plutarch use it almost exclusively in the territorial sense (with the exception of Diod. 40. 3.8 and, possibly, 14. 47.5). Strabo is situated somewhere in between these two extremes: the clear territorial meaning is present $(2.3 .4 ; 4.1 .14 ; 17.1 .5 ; 17.1 .46 ; 17.2 .3)$, but the more abstract meaning (e. g., "superiority") appears to be more frequent.

The meanings of both terms apparently changed in the century between Polybius and Diodorus. The pattern of use of both terms is significantly different in Diodorus and Plutarch, compared to Polybius. First of all, while there are numerous examples of the plural form of $\dot{\varepsilon} \pi \alpha \rho \chi \alpha$, referring to a number of administrative units (provinces, satra-

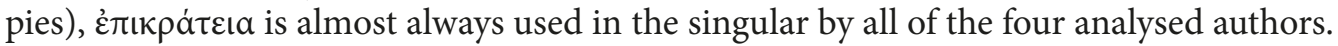
Among the 49 occurrences in total, 25 of which are clearly of a territorial character, the single exception to this rule is Diod. Sic. 40. 3. 8, describing the periods in which the Jews were ruled by foreigners (Persian and Macedonian). ${ }^{23}$ Such consistency cannot be regarded as a pure coincidence and, in turn, testifies to a difference in meaning between the two terms. Secondly, when we examine the vocabulary used to describe the Carthaginian position in Western Sicily closely, a surprising pattern emerges. While in general غ̇ंapxia is a much more popular term, appearing over 100 times in the Library of History and Lives, it is used only once in the context of the Carthaginian presence in Sicily (22. 10. 6). On


exception (40. 3. 8). Once again, this is striking consistency, suggesting that there indeed was a reason why Diodorus and Plutarch used this unusual terminology to describe the Carthaginian control over Sicily.

It is possible that both authors were influenced by a common source, probably $\mathrm{Ti}$ maeus of Tauromenion. Nevertheless, the arguments for such an influence are relatively weak. First of all, not only Diodorus and Plutarch, but also Polybius and Strabo (both used $\dot{\varepsilon} \pi ı \rho \rho \dot{\tau} \tau \varepsilon ı$ mostly in an abstract sense and outside of the Sicilian context) knew and referred to Timaeus' work. As a result, we cannot be sure how Timaeus himself understood this term, as it does not appear in any surviving fragments. It does, however, appear in

${ }^{23}$ Interestingly, there are cases in which Diodorus (Diod. Sic. 16. 82. 3) and Strabo (e. g., Strab. 11. 26. 2) refer to multiple states, where we find the singular, not the plural form. I am grateful to the anonymous reviewer who has brought it to my attention. 
Polybius' criticism of Timaeus' treatment of the bull of Phalaris (12. 25. $3=$ FGrH 566 F $28 \mathrm{~b}$ ), where the historian from Megalopolis uses the term in a more abstract sense - the bull was to be transferred to Carthage "in the times of the Carthaginian epikrateia" (кatò

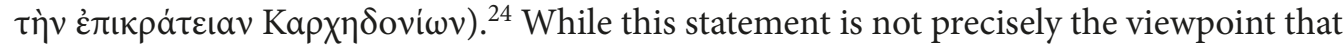
Polybius attributed to Timaeus, it may be reasonably expected that his criticism reflects the terminology present in the latter's work, especially since this matter was apparently thoroughly, if erroneously, discussed by Timaeus (Diod. 13. 90. 4-7=FGrH 566 F 28a).

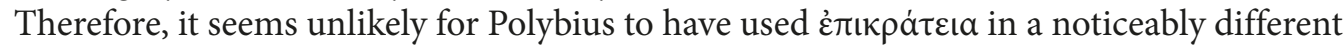
sense than it appeared in Timaeus, which leaves us with more evidence for an abstract meaning in Timaeus than for a territorial one. ${ }^{25}$

One could argue that Diodorus is particularly likely to reproduce Timaean terminology the most closely, since his dependence on Timaeus for his Sicilian narrative was widely accepted for a long time. ${ }^{26}$ However, an investigation into the use of Timaean material by Diodorus demonstrates that there is very little evidence to support this claim. Diodorus cited Timaeus' work usually when he gave different figures, e. g., for the size of the Carthaginian army (14. 54. 5-6), every time juxtaposing them with another source, or in the digressions, such as his description of Acragas (13. 82. 1-83. 4). Only once does the information taken from Timaeus provide a detail significant for the historical narrative (13. 85. 3). Therefore, Diodorus' complete dependence on Timaeus has to be taken with a pinch of salt. ${ }^{27}$

At this point, we lack sufficient evidence to support the hypothesis that Diodorus and

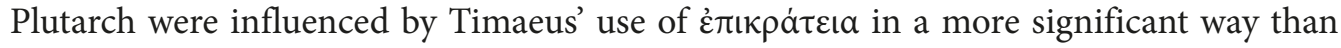
Polybius or Strabo.

Regardless of the origin of the latter term, the analysis indicates that in all the authors there is a significant difference in the way the terms $\dot{\varepsilon} \pi$ « particular in Diodorus and Plutarch. The main difference seems to be the absence of plu-

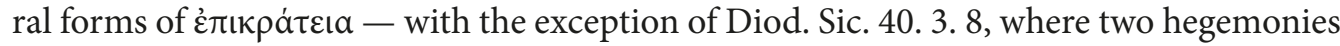

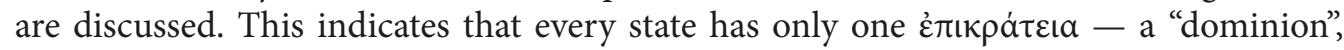
territory over which it has power, regardless of the precise legal status of each of its parts (cf. Strab. 2. 3. 4; 17. 1. 46). Therefore, this understanding brings to mind Polybius' use of the term $\dot{\varepsilon} \pi \alpha \rho x i \alpha$ (cf. Polyb. 2. 19. 2), but stands in stark contrast to what we have seen in Diodorus and Plutarch, where this term is used to describe a Roman province or its eastern and Hellenistic counterparts.

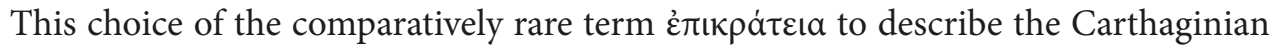
part of Sicily may seem surprising, considering that Greek offered a few other more common possibilities, such as $\delta v v a \sigma \tau \varepsilon i \alpha$ and $\eta \gamma \varepsilon \mu$ ovia, and raises the question of the relation-

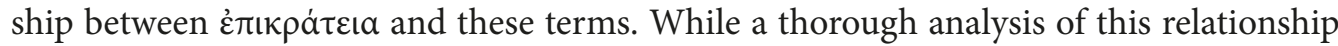
is beyond the scope of the present study, a few observations on the subject can be offered.

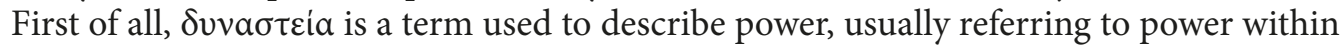

${ }^{24}$ On the bull of Phalaris see Walbank 1945, 39-42 and Dudziński 2013 with references to earlier scholarship.

25 While Polybius was certainly not above misrepresenting Timaeus when it suited his needs (for examples see Baron 2009), in this case one can hardly see the point of such a misrepresentation. On the other hand, the passage comes from the $12^{\text {th }}$ book of Histories, which survived only in Byzantine excerpts, which makes changes in terminology possible, albeit not particularly likely (see n. 15 above).

26 Volquardsen 1868, Meister 1967, Pearson 1987. Some scholars argued for the predominant role of Ephorus of Kyme (Stylianou 1998, 52-84) or Silenus of Kale Akte (e. g., Manni 1990 = Manni 1957-1958).

${ }^{27}$ For a more detailed analysis see Dudziński 2016. 
the state, and quite often to different forms of tyranny or monarchy (e. g., Diod. 14. 8. $4-$ tyranny of Dionysius I; 14. 32. 4 - oligarchy of the Thirty Tyrants in Athens; 20.77. 1 - a

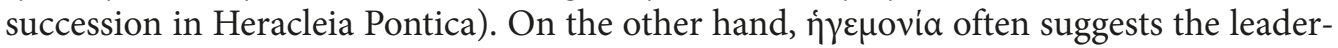
ship of a military alliance. ${ }^{28}$ It is clear that Diodorus perceived $\dot{\eta} \gamma \varepsilon \mu o v i \alpha$ and $\dot{\varepsilon} \pi \iota \kappa \rho \dot{\alpha} \tau \varepsilon ı$ as different terms - he uses the former only once in the context of Western Sicily, referring to the situation from the last quarter of the $6^{\text {th }}$ century, when the settlement of Heraclea by the Spartan prince Dorieus threatened the "hegemony of the Phoenicians" ( $\tau \tilde{\omega} v$ Фoเvík $\omega v$

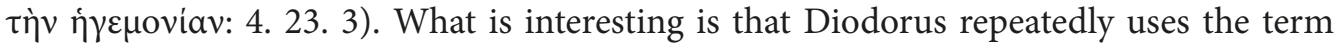
i $\gamma \varepsilon \mu o v i a$ to describe the Carthaginian empire elsewhere - in Libya and Sardinia (e. g., 12. 83. 6 ; 14. 77. 1; 15. 24. 2), but never uses this term for the Carthaginian part of Sicily.

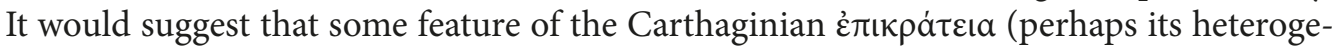

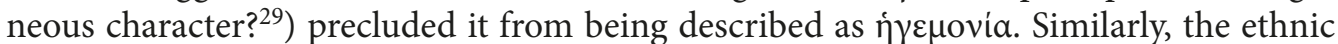
character of another term used by Diodorus, $\sigma v \nu \tau \dot{\varepsilon} \lambda \varepsilon \varepsilon a$, also makes it ill-suited to the

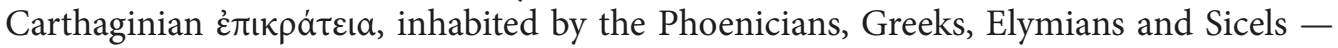
and possibly the others. ${ }^{30}$

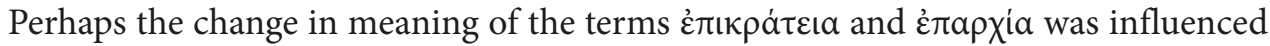
by the development, growing number and importance of the Roman provinces, fixed administrative units, which necessitated the use of a designated term. It seems that by the times of Diodorus the noun $\dot{\varepsilon} \pi \alpha \rho x i \alpha$ had become more precisely definable compared to how it was used by Polybius, and it described exclusively Roman provinces and similar administrative units. Consequently, authors like Diodorus, Strabo and Plutarch were forced to use a different term for the areas that were neither provinces or satrapies, nor hegemonies or alliances, but rather a mixture of a variety of communities and territories of a different status. The noun they chose seems to be $\dot{\varepsilon} \pi ı \kappa \rho \dot{\alpha} \tau \varepsilon ı .^{31}$

No matter what reasons we attribute to the change in meaning of $\dot{\varepsilon} \pi$ $\pi \rho \dot{\alpha} \tau \varepsilon ı$ and



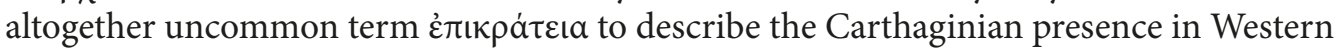
Sicily indicates that the ancient authors had some reservations about using another, more common nomenclature.

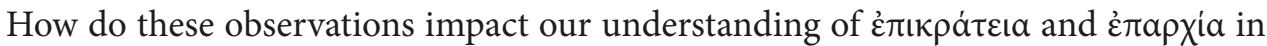

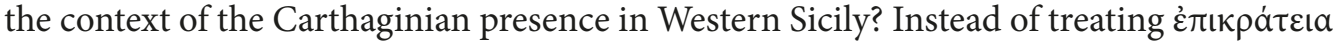
and $\dot{\varepsilon} \pi \alpha \rho \chi^{i} \alpha$ as synonymous, I propose we do precisely the opposite - consider that the

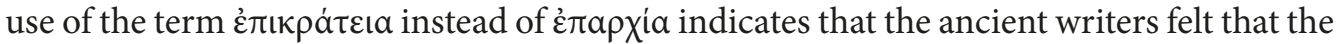
latter was inappropriate in the context of Carthaginian Sicily. Adopting such an approach will have, in my opinion, important consequences.

28 McDougall 1983, $\eta$ 4-6 offers (I) "command" and (II) "rule, supremacy, leadership".

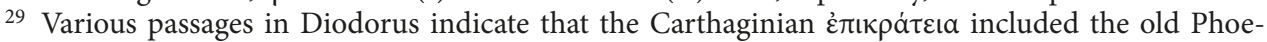
nician colonies (since Dionysius I blamed the "Phoenicians from the epikrateia" for incursions into his territory in 368, Diod. Sic. 15. 73. 1), the Elymian and Sican allies (e. g., note the Halykiai, Segesta and Entella remaining loyal to the Carthaginians in the face of Dionysius' aggression: Diod. Sic. 14.48.4; Halykiai

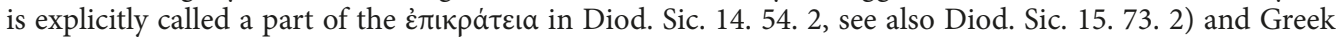
poleis - autonomous tributaries of the Carthaginians (e. g., Diod. Sic. 14. 41. 1; 47. 5; 15. 73. 2).

${ }^{30}$ For a discussion of Diodorus' use of $\sigma v v \tau \dot{\varepsilon} \lambda \varepsilon \varepsilon$ a see Cusumano 1996, 303-312. Cusumano (1996, 312) notes Diodorus' consistent use of the term throughout the Library of History and argues for its deliberate use by this author.

${ }^{31}$ It is worth noting that the evolution of meaning of both nouns was not followed by the verbs related to them, which maintain the same range of meanings they had in Polybius' times. 
First of all, it would indicate that the ancient authors - certainly Diodorus and Plutarch - were sensitive to the differences between provinces or satrapies and the character of Carthage's power.

Secondly, we should not frame the process of the evolution of the Carthaginian presence in Sicily into a model of linear progression, where $\dot{\varepsilon} \pi \iota \rho \alpha \dot{\tau} \varepsilon\llcorner\alpha$ is considered a protoprovince, only by the end of the $4^{\text {th }}$ century evolving into an $\dot{\varepsilon} \pi \alpha \rho \chi i \alpha$ (or, as Anello would argue, "vera e propria epikrateia"). ${ }^{32}$ While such an idea is certainly tempting, as it brings to the fore Carthage's growing control over her sphere of influence in Sicily, it may be concealing the complexity of this process.

\section{Conclusions}


dorus and Plutarch (and - in the case of the latter term - Strabo) leaves little doubt that $\dot{\varepsilon} \pi \alpha \rho \chi i \alpha$ and $\dot{\varepsilon} \pi \iota \kappa \rho \dot{\tau} \tau \varepsilon \iota \alpha$ could not have been used interchangeably. Especially Diodorus and Plutarch are very consistent in their use of these terms. Moreover, the same pattern of use for $\dot{\pi} \pi$ ı $\rho \alpha \dot{\tau} \varepsilon \iota a$ (almost always in the singular) in the territorial sense is observable also in Strabo's Geography, which indicates that it was not a technical term coined and used specifically for Carthaginian Sicily. It is clear that for all three authors - Diodorus, Strabo



These observations indicate that the meaning of both terms evolved over time. In

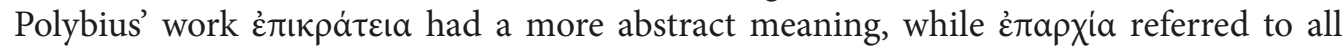
kinds of territorial control. The analysis of Diodorus and Plutarch proves that from the $1^{\text {st }}$

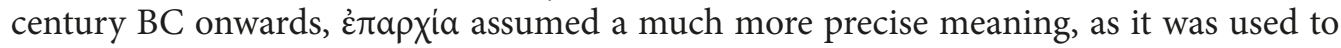
describe Roman provinces or their eastern and Hellenistic counterparts - administrative units governed by a single official appointed in the capital. At the same time, غ̇ was used by Diodorus and Plutarch to describe the Carthaginian presence in Western Sicily, while Strabo used it to determine the extent of a single state's whole dominion, regardless of the precise legal status of the territories.

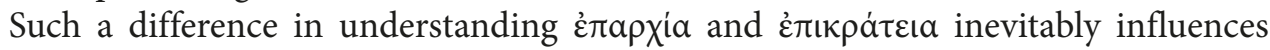
how we view the history of the Carthaginian presence in Sicily. In light of this analysis,

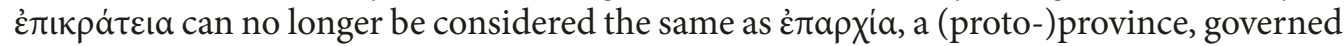
by the Carthaginians. Instead, we should understand it as a far less structured patchwork of states, peoples and territories, which recognised Carthage's superiority in various ways.

\section{References}

Ameling W. The Rise of Carthage to 264 BC, in: D. B. Hoyos (ed.) A Companion to the Punic Wars. Chichester, Wiley-Blackwell, 2011, 39-57.

Anello P. Il trattato del 405/4 a.C. e la formazione della <<eparchia>> punica di Sicilia. Kokalos 1986, 32, 115-179.

Anello P. Rapporti dei Punici con Elimi, Sicani e Greci. Kokalos 1990-1991, 36-37, 175-213.

Anello P. Punici e Greci dal 405/4 a.C. all'eta timoleontea, in: M. Congiu et al. (eds). Greci e Punici in Sicilia tra Ve IV secolo a. C. Caltanisetta, Sciascia, 2008, 81-100.

Bondi S. F. L'eparchia punica in Sicilia. Lordinamento giuridico. Kokalos 1990-1991, 36-37, 215-231.

32 E. g., Anello 1986, 176-177; Anello 1990-1991, 209; Bondì 1990-1991b, 261-262; Tusa 1990-1991, 166; Anello 2008, 97. 
Bonnet M. and Bennett E. R. (ed., comm., transl.). Diodore de Sicile. Bibliothèque historique. Livre XIV. Paris, Les Belles Lettres, 1997.

Cataldi S. Alcune considerazioni su eparchia ed epicrazia cartaginese nella Sicilia Occidentale, in: A. Corretti (ed.) Atti delle Quarte Giornate Internazionali di Studi sullarea Elima. Vol. 1. Pisa, Scuola Normale Superiore, 2003, 217-252.

Cusumano N. Sul lessico politico di Diodoro: synteleia, Kokalos 1996, XLII, 303-312.

De Vincenzo S. Tra Cartagine e Roma. I centri urbani dell'eparchia punica di Sicilia tra VI e I sec. a. C. Berlin - Boston, De Gruyter, 2013.

Dudziński A. The Bull of Phalaris and the historical method of Diodorus Siculus. Histos 2013, 7, 70-87.

Dudziński A. Diodorus' use of Timaeus, Ancient History Bulletin 2016, 30, 43-76.

Goukowsky P. (ed., comm., transl.). Diodore de Sicile. Bibliothèque historique. Fragments. Tome II. Livres XXI-XXVI. Paris, Les Belles Lettres, 2006.

Goukowsky P. (ed., comm., transl.). Diodore de Sicile. Bibliothèque historique. Fragments. Tome IV. Livres XXXIII-XL. Paris, Les Belles Lettres, 2014.

Hans, L.-M. Karthago und Sizilien. Die Entstehung un Gestaltung der Epikratie auf dem Hintergrund der Beziehungen der Karthager zu Griechen und den nichtgriechischen Volkern Siziliens, (VI.-III. Jahrhundert v. Chr.). Hildesheim - Zurich — New York, G. Olms Verlag, 1983.

Laqueur R. Timaios (3), in: RE 1936, VIA, 1076-1203.

Manafis P. (Re)writing History in Byzantium. A Critical Study of Collections of Historical Excerpts. LondonNew York, Routledge, 2020.

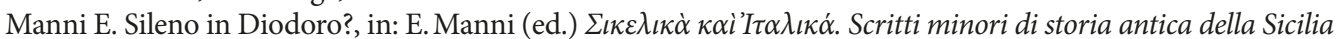
e dell'Italia meridionale. Vol. 1. Roma, Giorgio Bretschneider Editore, 1990, 599-605. = Manni E. Sileno in Diodoro? Atti Accademia di Scienze Lettere e Arti di Palermo 1957-1958, ser. VI, vol. XVIII.2, 81-88.

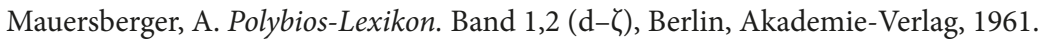

Mazzarino S. Introduzione alle Guerre Puniche. Milano, Rizzoli, ${ }^{2} 2003$.

McDougall J. I. Lexicon in Diodorum Siculum, Hildesheim — Zurich — New York, G. Olms Verlag, 1983.

Meister K. Die sizilische Geschichte bei Diodor von den Anfängen bis zum Tod des Agathokles, Munich, Munich Universität, phil. Dissertation, 1967.

Melliti K. Carthage. Histoire d’une métropole méditerranéenne. Paris, Perrin, 2016.

Miles R. Carthage Must be Destroyed: The Rise and Fall of an Ancient Civilization. London, Penguin Books, 2010.

Németh A. The Excerpta Constantiniana and the Byzantine Appropriation of the Past. Cambridge, Cambridge University Press, 2018.

Oldfather C. H. (ed., comm., transl.). Diodorus of Sicily. The Library of History. Books 14-15.19. LCL 399; Cambridge - London, Harvard University Press, 1954.

Palm J. Über Sprache und Stil des Diodoros von Sizilien: ein Beitrag zur Beleuchtung der hellenistischen Prosa. Lund, CWK Gleerup, 1955.

Pearson L. Greek Historians of the West: Timaeus of Tauromenium and His Predecessors. Atlanta, Scholars Press, 1987.

Rathmann M. Diodor und seine "Bibliotheke". Weltgeschichte aus der Provinz, Klio - Beiträge zur Alten Gescichte 27. Berlin - Boston, De Gruyter, 2016.

Richardson J. The Administration of the Empire. $C A H^{2}$, Vol.9, Cambridge, CUP, 1992, 564-598.

Sacks K. Diodorus Siculus and the First Century. Princeton, Princeton University Press, 1990.

Schwartz E. Diodoros (38), in: RE 1905, V, 663-704.

Stylianou P. J. A Historical Commentary on Diodorus Siculus, Book 15. Oxford, Clarendon Press, 1998.

Tusa V. L’epicrazia punica in Sicilia. Kokalos 1990-1991, XXXVI-XXXVII, 165-174.

Walton F. R. (ed., comm., transl.). Diodorus of Sicily. The Library of History. Fragments of Books 21-32. LCL 409; Cambridge - London, Harvard University Press, 1957.

Walbank F. W. Phalaris' Bull in Timaeus (Diod. Sic. XIII. 90.4-7). CR 1945, 59.2, 39-42.

Whittaker C. R. Carthaginian imperialism in the fifth and fourth centuries, in: P. D. A. Garnsey, C. R. Whittaker (eds). Imperialism in the Ancient World. Cambridge, CUP, 1978, 59-91.

Volquardsen Ch. A. Untersuchungen über die Quellen der griechischen und sicilischen Geschichten bei Diodor, Buch XI bis XVI. Kiel, Schwers'sche Buchhandlung, 1868. 